\title{
EVALUATING THE SUCCESS OF PEACE OPERATIONS
}

\section{Maja Garb \\ Faculty of Social Sciences, University of Ljubljana, Slovenia}

\begin{abstract}
Questioning and investigating the success of peace operations is not a new research activity. However, there are still many open questions, because the surveys do not show the same results. One of the crucial points in the analysis of the success of peace operations is a definition of such success. In this article, firstly, several debates on success evaluation, previously published definitions and criteria of success are explored, and some survey results are presented. Secondly, the evaluations of success of almost all peace operations made by students of International Relations and Defence Studies at the Faculty of Social Sciences in the study year 2008/2009 are presented and analysed. The success criteria used by the students in their evaluations comprise the main research question of the article. The analysis showed that three criteria were mostly used, namely fulfilment of the mandate or goals, the political and security situation, and assistance to the local population.
\end{abstract}

\section{Introduction}

The issue of questioning the success of peace operations is not particularly new. At least the lay persons' debates on peace operations describe many such operations as unsuccessful or even useless (from very different points of view). Especially the peacekeeping operations of the United Nations (UN) are quite often qualified as such. The organisations and institutions that lead peace operations sometimes respond to failures, especially the obvious ones, such as the fall of

Scientia Militaria, South African

Journal of Military Studies, Vol

42, Nr 1, 2014, pp. 44-63.

doi : $10.5787 / 42-1-1080$
Srebrenica in Bosnia and Herzegovina or the massacre in Rwanda. In that respect, the UN formed a panel "composed of individuals experienced in various aspects of conflict prevention, peacekeeping and peacebuilding, to assess the shortcomings of the existing 
system and to make frank, specific and realistic recommendations for change" - as has been said in the panel's report. ${ }^{1}$ Regarding the question of successfulness, the Report of the Panel on United Nations Peace Operations (2000) - the 'Brahimi report' for short - can be understood as a turning point in UN peacekeeping and peacebuilding. Nevertheless, other UN documents, such as An agenda for peace (1992), the 'Capstone Doctrine' (United Nations peacekeeping operations: Principles and guidelines, 2008), also have the aim of better functioning of the UN and of providing better outcomes of UN activities.

In the field of scientific research, the surveys on the success of peace operations are rather rare (although not completely absent). According to Diehl and Druckman -

An abundance of attention has been given to the inputs (or independent variables) in peace operation studies, and considerably less (if any at all) is given to the outcomes (or dependent variables); that is, most studies focus on the factors though to produce success rather than devoting attention to the criteria used to assess the success. $^{2}$

Similarly in Slovenia, in the empirical surveys on peace operations mostly done by the Defence Research Centre at the Faculty of Social Sciences at University of Ljubljana in the period 1999 to 2008 among the Slovenian Armed Forces $^{3}$ and Slovenian Police ${ }^{4}-$ much emphasis was placed on personnel in the operations and their preparations for the mission, their motivation, feelings and behaviour, and their personal experiences during the mission. ${ }^{5}$ The results and success of the operations with the presence of Slovenian soldiers and policemen were not systematically followed and evaluated in those surveys. However, there were some questions in the questionnaire for the Slovenian armed forces on the importance of international forces for the local security situation and host society and, in the questionnaire for the police, a question on the usefulness of the police peacekeepers' work during the mission. And also, since 2005, interviews with the police peacekeepers carried out after deployment contained a question on an evaluation of the importance and success of the peace operation. From the interviews with the police peacekeepers, it was evident that the opinions on the success of the mission differ in accordance with the mission, the period of the mission and also the work they have done during the mission. The evaluations of the contribution of the mission to development and local development in general ranged from totally pessimistic to more optimistic. ${ }^{6}$ The survey among Slovenian military peacekeepers in the $\mathrm{KFOR}^{7}$ in Kosovo in the years 2007-2008, for example, also 
found a somewhat indifferent attitude towards the success of the mission (after deployment, the respondents' mean evaluation of the statement "KFOR will provide peace and stability in Kosovo" was approximately 3 on the five-point scale). ${ }^{8}$ On the basis of those surveys, it can also be said that the executives in the missions (that is, the soldiers, policemen, civil experts, etc.) are often disappointed with the achievements of the peace operations. After the mission, they often say, "Nothing can be done" and "We just executed the orders". When that kind of pessimism reaches the general public, the negative attitude among civilians towards peace operations and missions is not a surprise. The question raised here is whether peace operations really are a waste of time, money and hope.

The article raises the question regarding evaluation of the success of peace operations, and presents and discusses the students' evaluations of peace operations and their successes. The main research question concerned the type of criteria the students used to assess the peace operations' success. The broader goal of the article is to contribute, with the review of peace operations' assessment methods, to the knowledge and practices of peace operations.

\section{Issue of defining success in peace operations}

Defining success is, firstly, one of the crucial points in the analysis of the success of peace operations. Secondly, the results of peace operations comprise long-term success rather than short-term success. The final goal of peace operations should be a termination of conflict and setting the stage for lasting peace and development. One of the success categorisations differentiates between success on a strategic level and success on an operational or even tactical level. ${ }^{9}$ According to the distinction, it could be assumed that fulfilment of the operational goals is an urgent, but not a sufficient condition for success in the strategic or even political sense.

In his book International peacekeeping (1993), Paul Diehl identifies two criteria for evaluating peacekeeping operations: limiting armed conflict and promoting conflict resolution. Diehl employs these two standards to measure the success of peacekeepers in six cases:

- $\quad$ UNEF I on the Egyptian-Israeli border from 1956 to 1967;

- $\quad$ UNEF II from 1973 to 1979 ;

- $\quad$ ONUC in the Congo from 1960 to 1964 ;

- $\quad$ UNFICYP in Cyprus from 1964 onward;

- UNIFIL in Lebanon from 1978 onward; and

- $\quad$ the US-led Multinational Force in Lebanon from 1982 to $19844^{10}$ 
According to his study, Diehl concludes that peacekeeping operations are most successful under these conditions:

- The host states and third parties give their consent to peacekeeping operations;

- $\quad$ Peacekeepers are lightly armed and do not fire except in self-defence;

- $\quad$ Peacekeeping forces maintain a neutrality in which they neither favour nor are perceived to favour any side in the dispute;

- $\quad$ Peacekeeping addresses interstate rather than intrastate conflicts; and

- The geographic context enables peacekeepers to be deployed in relatively invulnerable settings in which they can easily detect violations and completely separate the combatants. ${ }^{11}$

Since Diehl's book is one of the first publications on the evaluation of the success of peace operations, there are several critiques of his work and the criteria he used. There are some doubts about Diehl's methods and conclusions, ${ }^{12}$ but also understandings of different possible frameworks for analysis and standards for evaluation. $^{13}$

According to Johansen,

... scholars and journalists should no longer measure peacekeeping against an ideal state of peace (for example, no armed conflict after deployment) or against an ideal form of conflict resolution (for example, settlement of long-standing animosities). To do so is normatively unfair and scientifically unproductive. ${ }^{14}$

Johansen instead suggests -

... to find the utility of peacekeeping, we should (1) assess the effect of peacekeeping forces on local people affected by their work, and (2) compare the degree of misunderstanding, tension, or violence in the presence of UN peacekeepers to the estimated results of balanceof-power activity without peacekeeping. ${ }^{15}$

In 1996, Duane Bratt used four indicators to measure operational success:

- Did the operation complete its mandate?

- Did the operation facilitate a resolution to the conflict?

- Did the operation contain the conflict? 
- Did the operation limit the casualties of combatants, civilians and peacekeepers? ${ }^{16}$

Using the criteria of mandate performance, facilitation of conflict resolution, conflict containment and limitation of casualties, Bratt assessed the success of the 39 UN peacekeeping operations that were conducted from 1945 to 1996. From his analysis, Bratt derived three levels of operational success:

- A successful operation is one which has facilitated a resolution to the conflict;

- A moderately successful operation occurs when one of the remaining three objectives has been substantially fulfilled; and

- Finally, a failure would be an operation which failed under all four indicators, or which only had limited success in one of the measurements. ${ }^{17}$

Darya Pushkina (2006) went one step further and wanted to answer the question of success determinants, that is, the question why the UN has been more successful in managing some internal conflicts than others. Despite a new study issue, she also could not avoid the question of criteria for success. She tried to elaborate on these. The following broader criteria were used in her research:

- $\quad$ Limiting violent conflict in the host state (primary goal of peacekeeping);

- Reducing human suffering (another primary goal of peacekeeping missions);

- $\quad$ Preventing the spread of conflict beyond the object state's borders; and

- Promoting conflict resolution.

Pushkina studied 17 UN peacekeeping missions between 1945 and 1998 in which UN troops were deployed. After the examination following the criteria mentioned above, the missions were classified into three groups:

- $\quad$ Successful (UNTAG, ONUMOZ, UNTAES, UNSMIH, UNMIH, UNPROFOR-Macedonia, UNPREDEP);

- $\quad$ Partially successful (UNFICYP, UNTAC, ONUC); and

- $\quad$ Failed (UNAVEM III, UNIFIL, UNOSOM II, UNPROFOR-Croatia, UNCRO, UNPROFOR-Bosnia, UNAMIR) ${ }^{18}$.

As the author noted, the successful missions implemented most elements of their mandates, sustained ceasefires, prevented outbreaks of major violence, reduced the number of casualties, assisted resettlement of refugees and internally 
displaced people, and created safe environments in which large-scale violence did not occur after peacekeeping missions had left. Failed missions, on the other hand, tended to exhibit the opposite features, such as that violence persisted, war-related casualties continued, and both warring parties committed severe human rights abuses. ${ }^{19}$ The study confirmed the hypothesis that UN peacekeeping is more successful in civil conflict management when:

- UN members demonstrate consistent commitment to resolving the conflict;

- UN peacekeeping is accompanied by effective diplomacy;

- The warring parties give their consent to and cooperate with the UN peacekeeping mission;

- There is a perception on the part of the warring parties that conflict should be resolved by non-violent means; and

- UN peacekeeping is less successful in civil conflict management when one or both of the warring parties is supported militarily and/or politically by outside states or groups during the period of UN mission deployment.

Thus the question of success determinants can be answered to the effect that the level of UN commitment, outside support, diplomatic efforts, consent of warring parties with the UN mission and commitment of warring parties to nonviolent means correlate with the success of the peacekeeping mission. ${ }^{20}$

Jaïr van der Lijn (2010) mentions nine factors for success and failure of peacekeeping operations that were found in the literature. ${ }^{21}$ He does not discuss the success definition or criteria, although he uses the term 'durable peace' and identifies factors that explain differences in contribution to durable peace by the UN peacekeeping operations. It is obvious that contributing to durable peace is, for Van der Lijn, the main criterion for assessing the success of peace operations. Van der Lijn concludes that the probability for a peacekeeping operation making a positive contribution to durable peace increases if:

- The parties are sincere and willing to cooperate with the implementation of the operation;

- The operation is able to provide a sufficient sense of security to the parties;

- The operation pays sufficient attention to the causes of the conflict both in depth and in breadth; 
- The operation receives co-operation from important outside actors and parties;

- The operation is deployed at the right time;

- The operation is implemented by competent personnel under competent leadership and with clear command structures,

- The operation is part of a long-term approach;

- The 'policy tools' implemented in the operation are coordinated within the operation, as well as externally; and

- The operation provides 'ownership'. ${ }^{22}$

He further claims that the first three factors have so far appeared to be the most important.

Donna Winslow writes about differences in understanding of the success of peace operations by various actors. Non-governmental organisations (NGOs) may not declare the mission successful until all human suffering has been alleviated in the area. Public opinion and the media may simply want to put an end to fighting. The national politicians may also have another definition of success, such as no casualties in the field, good publicity for the government, etc. The military's definition of success is determined by the mission that has to be accomplished. Winslow also found that, for the military, especially for the commanders, the mission is often considered successful if their troops sustain no casualties and are brought home safely - even if the actual mandate was not completely fulfilled. ${ }^{23}$

Lately success in peace operations has been a research object of Hermann Jung as well, who warns of the importance of goal congruence (or coherence or compliance) among national military contingents, other international actors, and the host nation's culture, expectations and goals. Based on some sociological and communication theories, he assumes that the success of peace support operations is also determined by the goal congruence of various actors. Jung further introduces a domestic population factor into the evaluation of the success of peace operations. ${ }^{24}$

The organisations that usually conduct missions have also defined the success criteria for their own missions. The UN put the success criteria and factors for peacekeeping in its "Capstone Doctrine" (United Nations peacekeeping operations: Principles and guidelines 2008). The factors proclaimed by the UN as essential for success of peacekeeping operations are: 
- Consent, impartiality and the non-use of force except in self-defence and defence of the mandate;

- Perception of legitimacy and credibility of operations particularly in the eyes of local population; and

- Promotion of national and local ownership, in order to contribute to the achievement of a sustainable peace. ${ }^{25}$

According to the UN, other important factors that help drive the success include:

- Genuine commitment to a political process by the parties in working towards peace (there must be a peace to keep);

- Clear, credible and achievable mandates, with matching personnel, logistic and financial resources;

- Unity of purpose within the Security Council, with active support for the UN operations in the field;

- Host country commitment to unhindered UN operations and freedom of movement;

- Supportive engagement by neighbouring countries and regional actors;

- An integrated UN approach, effective coordination with other actors on the ground and good communication with host country authorities and population; and

- The utmost sensitivity towards the local population and upholding the highest standards of professionalism and good conduct (peacekeepers must avoid becoming part of the problem). ${ }^{26}$

In addition to general factors of success that the UN peace operations and forces should fulfil, the financial, conduct and also other aspects of UN activities are regularly monitored by the UN's Office of Internal Oversight Services (OIOS). This body was established in 1994 "as an operationally independent office that assists the Secretary-General in fulfilling his internal oversight responsibilities in respect of the resources and staff of the Organisation ${ }^{27}$ through monitoring, internal audit, inspection, evaluation and investigation" ${ }^{28}$ The peace operations activities are part of the oversight, too. According to its annual reports, OIOS issues around 200 oversight reports yearly. ${ }^{29}$ It is interesting that the problem of sexual exploitation and abuse is usually the issue investigated most often. The majority of recommendations in these reports are attributed to the operational aspects of 
operations (such as risks arising from inadequate, inefficient or failed internal processes or failure to conduct operations economically, efficiently or effectively). ${ }^{30}$

The European Union (EU), as far as it can be seen, has not evolved its specific set of success criteria for its Common Security and Defence Policy (CSDP) missions yet. There are many analyses and articles that check and want to prove the usefulness of CSDP and EU missions and operations, while the comprehensive evaluation of individual missions is rarely the case. An important step in this direction was made by a book European Security and Defence Policy: The first 10 years (1999-2009), published in 2009 by the European Union Institute for Security Studies. ${ }^{31}$ This publication presents all EU operations in the framework of the European security and defence policy until 2009, including their achievements and lessons learned. The evaluation criteria are wide-ranging. The authors namely pointed out the achievements such as fulfilment of the mission's core tasks (developing the local police by the European Union Police Mission [EUPM], disarmament and demobilisation of rebel groups by Aceh Monitoring Mission, etc.), mandate fulfilment (Althea ${ }^{32}$ ), credibility test of the EU (Concordia ${ }^{33}$ ), developing an innovative and cost-efficient mission concept (EUJUST LEX ${ }^{34}$ ), etc. Together with the achievements, some shortcomings of these missions are highlighted, such as coordination problems, logistical insufficiencies, lack of sound authority on the ground, etc. Nevertheless, the common criteria for CSDP missions are difficult to set due to the EU practice that the missions are tailored specifically for each case.

NATO defined success in its peace support operations in the Allied Joint Publication (AJP) 3.4.1 on peace support operations that was accepted in July 2001. As stated in the AJP, in peace support operations, success will generally be related to the achievement of a number of pre-determined strategic objectives, which form elements of the overall political end-state. The nature of peace support operations is such that these objectives will normally relate to the establishment of a secure, stable and self-sustaining environment for the local population. ${ }^{35}$ The strategic objectives that are seen in political situations and in the end-state are completed with a lower level of goals, namely the military goals. These are important benchmarks of overall success (secure environment for local population, demobilisation and retraining of former combatants, for example). The military goals should also outline the military profile of the operation and withdrawal of military forces (with successful transition to other forces). However, as stated in NATO AJP 3.4.1 -

... the achievement of the military objectives and the creation of a secure environment do not guarantee the establishment of a selfsustaining peace. But without security (and justice), the 
reconciliation, reconstruction and development programme necessary to create a self-sustaining peace are unlikely to be effective. However, once the security-related military objectives have been achieved, the attainment of the political end-state will require the mission's main effort to be switched from PSF to the peace building activities of the civilian components of the mission. Without such a switch of main effort and a commensurate switch of funding and resources, the operation is unlikely to progress beyond of a military stalemate. ${ }^{36}$

The factors affecting success in NATO peace support operations are the following:

- $\quad$ Peace support forces must be adequately led, trained, organised, equipped and armed - that will give them credibility;

- $\quad$ Peace support forces must be strictly impartial; and

- The professional conduct of the peace support forces must reinforce all aspects of the conduct of the mission.

Besides these, there are also many other factors that can inhibit the possibility of success, which should be taken into consideration, such as a lack of support of the international and local community, tensions among combat and peace support operations, cultural aspects, complexity of peace support operations in general, feelings of impotence caused by limited rules of engagement, etc. ${ }^{37}$

After this review of the literature on assessing the success in peace operations, it is obvious that the evaluation of the success of peace operations is strongly connected with the criteria selection. These are defined differently by different authors and institutions, although some common understanding of the criteria can be seen from the review, too. Mandate fulfilment may be the simplest criterion but many authors suggest that success should be evaluated in broader terms, such as reducing violence and promoting conflict resolution.

\section{Success of peace operations: students' assignments on peace operations}

As seen above, several authors analysed the success of peace operations, although the selection of the operations taken into account is usually very limited. The conducting organisations make evaluations of their operations for themselves and for different purposes. Among the purposes, the lessons learned and the international support for organisations' endeavours are definitely two of the most 
important. But, from an academic point of view, the overall assessment of the success of peace operations is important, too. The general question, "Is a peacekeeping mission successful?" is often raised by researchers and teachers in the field of international security. The students of the Course on Peace Operations completed an assignment in this regard in the study year 2008/2009. In this article, the most interesting results are presented and discussed according to the evaluations and studies presented in the first part of the article.

As an introduction to the methodology, some introductory information on the study course and the student assignment is provided. The Faculty of Social Sciences at the University of Ljubljana in Slovenia revised and renewed its study programmes in 2005. Among the undergraduate courses, a new course called Peace Operations was developed. The course content was partly derived from the empirical surveys on police and military in peace operations and partly from theoretical approaches to important issues in the field of peace operations. The course was presented for the first time in the study year 2008/2009. The students wrote an essay (a seminar work), as part of their study obligations during the course. In that year, the topic of the seminar work pertained to a description and evaluation of a particular peace operation/mission. The students could choose the operation freely from a list of all operations and missions of the United Nations, the European Union, the North Atlantic Treaty Organization (NATO) and the Organization for Security and Cooperation in Europe (OSCE) between 1948 and October 2008. There were 119 operations and missions on the list. The students could also choose the research question that they wanted to answer in the seminar work out of three prescribed, ${ }^{38}$ but all of them had to assess the success of the operation/mission at the end of the essay. The exact indicators or criteria for the assessment were not prescribed. The students could therefore freely decide how to analyse and describe the success of the peace operation. This assignment was completely new for them since the topic of the success of peace operations was not part of the course lectures at that time. The students just received some pointers on how to approach that particular assignment. The students came mostly from the $3^{\text {rd }}$ and $4^{\text {th }}$ grade of study of International Relations and Defence Studies.

The students were given the assignments in October 2008 and they had approximately two months to write the essays. At the end of the course, 97 essays which meant 97 analyses of peace operations or missions - had been done. Among them, there were 59 analyses of missions by the UN, 15 of missions by OSCE, 17 by the EU and 6 by NATO. The success assessment always formed the last section of the seminar work (as it was instructed) and included a text of about half a page to 
one page long. All 97 papers together offered a quite relevant "database" on peace operations and their successes.

In the analysis of the students' papers, attention was paid to the respective elements of the essay, namely the organisation/institution that conducted the operation/mission, the country/territory of the operation/mission, the key task of the operation/mission, and finally, the evaluation of the success of the operation/mission. Regarding the last element, the analysis focussed on the criteria that were used and the results of the evaluation. While the students were not instructed which success criteria had to be used in their evaluation, it was interesting to see which criteria/elements they had chosen. The content analysis of these evaluations showed that the students evaluated/assessed the success of the missions mainly through one or more of the following three elements:

- Fulfilment of mandate or goals;

- Political and security situation; and

- Assistance to local population.

Regarding the mandate and goals of the mission, students generally concluded that these had been fulfilled. Regarding the political and security situation, students concluded that, after the mission, in many cases there were not many improvements, but sometimes the missions had succeeded in preventing a war. Regarding assistance to the local population, the students generally concluded that the missions achieved success in humanitarian assistance.

In addition, many students talked about the prolongation of the mission as a sign of success. For many of them, the prolongation of the mission was a clear sign of a successful mission, because "why would the organisation prolong an unsuccessful mission?" There were also some statements to the opposite, namely that the prolongation proved that the mission did not achieve its goals but got another chance.

An additional element in the evaluations was promotion or development of the organisation itself while it prepared and conducted the particular mission. It was an interesting evaluation outcome, irrespective of the obvious fact that these evaluations stemmed from the resources that students used for their mission evaluations (mainly the official reports of the organisation that conducted the peace operation).

The students also realised that the mission, its mandate and people were not the only factors of success. Many outside factors were often decisive, 
particularly international and national political interests and political will. From some assessments, it could be concluded that many missions would be more successful and many conflicts less destructive and resolvable if only the important political actor simply wanted that. Such a conclusion is comparable with the opinions of peacekeepers at the executive levels of the mission who often say, "We do, what we can! The rest is in the hands of politicians!"39

Despite the fact that all the evaluations made by the students were descriptive, it was possible to reach a conclusion on the success or lack of success of the missions. According to these particular evaluations, the best evaluations were attributed to -

- $\quad$ European Union Police Mission in Macedonia (EUPAT);

- $\quad$ European Union political and rule of law mission in Iraq (EUJUST LEX);

- Interim military mission in the Democratic Republic of the Congo (Artemis);

- $\quad$ Support mission to the African Union mission AMIS in Darfur;

- NATO Operation Active Endeavour in the Mediterranean;

- The OSCE mission (office) in Tajikistan; and

- $\quad$ Some United Nations operations/missions such as -

- $\quad$ peacebuilding mission UNMIT in East Timor;

- observer mission UNOGIL in Lebanon;

- $\quad$ monitoring mission UNMOGIP in India and Pakistan;

- UN military observer mission UNOMSIL in Sierra Leone;

- $\quad$ observer mission UNAVEM I in Angola;

- $\quad$ support mission UN SMIH in Haiti;

- UN integrated mission UNAMSIL in Sierra Leone;

- $\quad$ implementation mission ONUCA in Central America; and

- $\quad$ transitional assistance group UNTAG in Namibia).

Implementation missions, on average, received better evaluations. It can also be said that the assessments of all missions together gave the impression that the operations and missions were in general successful. The EU missions in general were evaluated as the most successful, while the UN and NATO missions were regarded as less successful. Of course, these evaluations had to be taken with some reserve, because the resources and criteria used for them were not the same in all cases.

Despite the fact that the analyses made by the students did not fulfil all conditions of scientific research (absence of the common list of indicators/criteria 
for success, for example), the students' studies could answer at least two questions. First, which criteria did students mostly use for their evaluations, and second, did these criteria coincide with criteria used in other studies regarding the success of peace operations?

Regarding the first question, we can say that three criteria were mostly chosen for the evaluations, namely fulfilment of mandate or goals; political and security situation; and assistance to local population. Additionally, some other criteria were used as well, such as the duration of the mission and the development of the organisation or its peacekeeping itself. We can see that the students actually used the criteria that other authors mostly used or suggested in their studies. Especially the mandate criterion was one of the most popular evaluation criteria for the researchers and practitioners. The use of the security and political situation criterion by the students also confirmed some other studies, for example, the Diehl study (both criteria limiting armed conflict and promoting conflict resolution). The criterion of assistance to the local population, which was used by the students, was an interesting one, not because of its uniqueness (one of the main goals of the missions should be the reduction of human suffering $)^{40}$ but in terms of the general finding of the students, namely that the missions are successful in fulfilling that task. Using the time perspective - the duration of the mission - as the success criterion is ambiguous. Students also showed that in their evaluations. The prolongation of a mission was used as a sign of success but also as a sign of failure. The same is also valid for the termination of a mission. This ambiguity reflects well in Pushkina's finding that the duration of a mission's deployment cannot be used as an indicator of the success of a mission. ${ }^{41}$ The finding that missions can also be used for organisational development was not a surprise, although it seems a little odd, especially if we understand missions as enterprises that should help societies in conflict or in post-conflict recovery. On the other hand, all institutions grow out of their activities. And a successful mission is evidence of the right orientation and work of the institution or organisation.

When the success of missions is considered through the organisations, it can be concluded that the missions of the EU and OSCE are the most successful ones. This is not surprising when we remember that they both take over the missions in either a late phase or they establish peacebuilding missions that do not involve the use of military force. Peace enforcement missions, such as NATO missions, have much fewer clear positive outcomes. At least that could be derived from the students' studies. 
Finally, two more points should be mentioned. On the one hand, various written analyses and reports are convenient to evaluate the success of peace operations, but on the other hand, the reports as general documents sometimes show a somewhat different picture than direct experiences on the terrain. ${ }^{42}$ The second important point is that many students argued that, for a successful mission, a strong political will and political commitment are of key importance. Many practitioners confirm the importance of political will for the success of a mission. Peace operations and missions are never just military obligations but rather political ones as well.

\section{Conclusion}

The evaluation of the success of peace operations (and, probably, of all other reconstruction efforts) rest largely on the success criteria used. Various authors used a few identical but also a few quite different criteria to evaluate the success of various peace operations, for example,

- Diehl used two criteria, namely limiting armed conflict and promoting conflict resolution;

- Johansen suggested two routes, completely different from Diehl's criteria - first, to assess the effect of peacekeeping forces on local people affected by their work, and second, to compare the degree of misunderstanding, tension or violence in the presence of the UN peacekeepers to the estimated results of balance-of-power activity without peacekeeping;

- Bratt used four indicators - mandate performance, facilitation of conflict resolution, conflict containment and limitation of casualties;

- Pushkina used four criteria - limiting violent conflict in the host state, reducing human suffering, preventing the spread of conflict beyond the object state's borders, and promoting conflict resolution; and

- Van der Lijn used the term 'durable peace'.

Additionally, the organisations that lead the operations have their own measures to evaluate the operations/missions. In the organisations' documents, there are listed factors that influence the success of the operation/mission (from non-use of force except in self-defence [one of the UN factors] to cultural aspects, one of the success factors of NATO) rather than success criteria. As shown by the surveys by these authors and organisations, the analysis of the students' work (with no determined criteria, they gave only limited results in evaluating the success of the mission), showed that there is a need for a multi-criteria approach or a 
comprehensive approach to assess the success of peace operations/missions. The results of the operations/missions are often blurred. However, as Pushkina emphasises, limiting the armed conflict and people's suffering should be the primary goal of peace operations/missions and the utmost criterion of their success. But the reality of operations/missions shows that the efforts of peacekeepers are often influenced by narrower national interests of contributing countries and, as Winslow pointed out, a fear of casualties among the peacekeepers.

Regarding the students' approaches on the topic of the success of peace operations, it can be said that the students took their assignment very seriously. They generally tried to list the achievements and failures of the operation or at least summarised the success assessment from the documents. Despite not being instructed to do so necessarily, some of them paid attention to the criteria for success evaluation as well. The students' analyses and success evaluations showed substantial personal and expert maturity and knowledge. The interest of the students and their recognition of the particular topic became clear in the next two study years when the success of peace operations became an important topic in the teaching on peace operations. The students showed good knowledge on that particular topic in the final exams. In addition, some students decided to do further research and finished (or will finish in the near future) their studies with a diploma on the success of peace operations. ${ }^{43}$

The analysis of the students' evaluations showed that the operations that were assessed as more successful than the other are the implementation operations and the operations that were taken over in a late phase (the EU operations, for example). Bearing in mind that (expected) finding, we can better understand the frequent reluctance of international organisations as well as states to establish a new operation in contested regions, especially an operation with the enforcement mandate.

Regarding the broader goal of the article, namely the contribution to the knowledge and practices of peace operations, it can be concluded that the review of available literature on the evaluation of the success of peace operations showed that such an extensive evaluation has not been done so far. Various authors selected just a few operations to analyse the success, but the analysis reported here is comprehensive and systematic. The bulk of students' evaluations presented and discussed in the article contribute to the extent of knowledge on the success of peace operations. However, there is room for more intensive surveys on the matter. 


\section{Endnotes:}

${ }^{1}$ See the Executive Summary of the Report of the Panel on United Nations Peace Operations. United Nations, General Assembly and Security Council A/55/305-S/2000/809, 21 August 2000.

<http://www.un.org/peace/reports/peace_operations/> Accessed on 28 June 2013.

${ }^{2}$ Diehl, PF \& Druckman, D. Evaluating peace operations. Boulder, CO: Lynne Rienner, 2010, 1.

${ }^{3}$ Slovenian Armed Forces were firstly deployed to an international mission in 1997 - in international operation ALBA in Albania. Since then, the members and troops of Slovenian Armed Forces were sent into more than 20 international missions (see the homepage of the Slovenian Armed Forces at www.slovenskavojska.si).

${ }^{4}$ The Slovenian Police were firstly deployed to an international peace mission in 1997 - in operation MAPE in Albania. Since then, the members of the Slovenian police were sent into more than 15 international civilian missions (see the homepage of the Slovenian Police at www.policija.si).

${ }^{5}$ See for example Jelušič, L, Garb, M, Vegič, V \& Juvan, J. "Slovenska vojska v mirovnih operacijah: cilji in rezultati prve faze empiričnega raziskovanja". Slovenska vojska 12/5. 12 March 2004. Appendix, 1-15; and Garb, M \& Jelušič, J. "Slovenska policija v mirovnih misijah: rezultati empiričnega raziskovanja". Varstvoslovje 4/3. 2002. 204-214.

${ }^{6}$ The survey among Slovenian police peacekeepers was carried out in 2000 to 2008 by the Defence Research Centre from the Faculty of Social Sciences at the University of Ljubljana. It consisted of two methods - the opinion poll before the deployment and the interview after it.

${ }^{7}$ KFOR - Kosovo Force (NATO).

${ }^{8}$ The Defence Research Centre at the Faculty of Social Sciences at the University of Ljubljana carried out several major empirical research projects on Slovene military in peace operations (in 2003-2008). Some results were also published in the international milieu (for example Jelušič, L. "Motivation for peace operations". Revue internationale de sociologie. 17/1. 2007; Vegič, V. "The effects of previous development on soldiers' attitudes to peace operations". International Peacekeeping. 14/2. April 2007; Juvan, J \& Vuga, J. What motivates Slovenian 'peacekeepers'?” International Peacekeeping 18/1. January 2011, etc.).

${ }^{9}$ NATO AJP-3.4.1. Peace Support Operations, July 2001. 
${ }^{10}$ UNEF I, II - United Nations Emergency Force; ONUC - United Nations Operation in the Congo; UNFICYP - United Nations Peacekeeping Force in Cyprus; UNIFIL - United Nations Interim Force in Lebanon.

${ }^{11}$ Johansen, RC. "UN peacekeeping: How should we measure success?" Mershon International Studies Review 38. 1994. 307-308.

12 Ibid., pp. 307-310; Segal, DR. "International peacekeeping" (book review). Armed Forces \& Society Fall 1994.

13 Druckman, D \& Stern, PC. "Evaluating peacekeeping missions, Mershon". International Studies Review 41/1. May 1997. 151-165.

${ }^{14}$ Johansen op. cit., p. 309.

${ }^{15}$ Ibid., pp. 309-310.

${ }^{16}$ Bratt, D. "Assessing the success of UN peacekeeping operations". International Peacekeeping Winter 1996. 64-81; Bratt, D. "Explaining peacekeeping performance: The UN in internal conflicts". International Peacekeeping 4/3. Autumn 1997. 46.

${ }^{17}$ Bratt, "Explaining peacekeeping performance ..." op. cit., p. 46.

${ }^{18}$ UNTAG - United Nations Transition Assistance Group ; ONUMOZ - United Nations Operation in Mozambique; UNTAES - United Nations Transitional Authority in Eastern Slavonia, Baranja and Western Sirmium; UNSMIH United Nations Support Mission in Haiti; UNMIH - United Nations Mission in Haiti; UNPROFOR - United Nations Protection Force; UNPREDEP United Nations Preventive Deployment Force; UNFICYP - United Nations Peacekeeping Force in Cyprus; UNTAC - United Nations Transitional Authority in Cambodia; ONUC - United Nations Operation in the Congo; UNAVEM III - United Nations Angola Verification Mission III; UNIFIL United Nations Interim Force in Lebanon; UNOSOM II - United Nations Operation in Somalia II; UNCRO - United Nations Confidence Restoration Operation in Croatia; UNAMIR - United Nations Assistance Mission for Rwanda.

${ }^{19}$ Pushkina, D. "A recipe for success? Ingredients of a successful peacekeeping mission”. International Peacekeeping 13/2. June 2006. 135.

${ }^{20}$ Ibid., pp. $145-147$.

${ }^{21}$ The methodology has been developed in Van der Lijn, J. Walking the tightrope: Do UN peacekeeping operations actually contribute to durable peace? Amsterdam: Rozenberg, 2006.

${ }^{22}$ Van der Lijn, J. "Success and failure of UN peacekeeping operations: UNMIS in Sudan". Journal of International Peacekeeping 14. 2010. 29-33.

${ }^{23}$ Winslow, D. "Strange bedfellows: NGOs and the Military in humanitarian crises". The International Journal of Peace Studies 7/2. Autumn/Winter 2002. 
${ }^{24}$ An early version of Hermann Jung's paper was presented at the ERGOMAS 11th Biennial Conference in Amsterdam, 13-17 June 2011.

${ }^{25}$ United Nations. Department of Peacekeeping Operations, Department of Field Support. United Nations peacekeeping operations: Principles and guidelines. New York, 2008, 31-40.

26 United Nations Peacekeeping. "Success in peacekeeping". 〈http://www.un.org/en/peacekeeping/operations/success.shtml> Accessed on 20 July 2011.

${ }^{27}$ United Nations.

28 United Nations Office of Internal Oversight Services. <http://www.un.org/Depts/oios/> Accessed on 19 March 2014.

${ }^{29}$ According to the annual reports, the Office of Internal Oversight Services issued 160 oversight reports related to peace operations in 2012, 194 in 2011,195 in 2010, 214 in 2009, 199 in 2008, etc.

30 See the annual reports of Office of Internal Oversight Services, available at http://www.un.org/Depts/oios/pages/annual_reports.html.

${ }^{31}$ Grevi, G, Helly, D \& Keohane, D (eds). European Security and Defence Policy: The first 10 years (1999-2009). Paris: European Union Institute for Security Studies, October 2009.

${ }^{32}$ EUFOR Althea - military mission of European Union in Bosnia and Herzegovina.

${ }^{33}$ EUFOR Concordia - military mission of European Union in Macedonia.

${ }^{34}$ EUJUST LEX - The European Union Integrated Rule of Law Mission for Iraq.

${ }^{35}$ NATO AJP-3.4.1. Peace Support Operations, July 2001, 2-2.

${ }^{36}$ Ibid.

${ }^{37}$ Ibid., pp. 2-2, 2-3.

38 1. How was the operation/mission established and conducted (international law aspect)? or 2. What are the personnel problems in the operation/mission? (human resources aspect)? or 3. What kinds of tasks should the operation (mission) fulfil and what are the trouble spots of the mission operating (operational aspects)?

${ }^{39}$ This is one of the findings from the survey of the Slovenian Police in the Peace Missions that was carried out in 2000 to 2007 by the Defence Research Centre, Faculty of Social Sciences, University of Ljubljana.

${ }^{40}$ Pushkina op. cit., pp. 133-149.

41 Ibid.

${ }^{42}$ As shown by the empirical survey on Slovenian police-peacekeepers (see note 6).

43 Štibelj, M. "Uspešnost misije MINUSTAH". Diploma thesis. University of Ljubljana, 2013; Gruden, E. "Uspešnost mirovnih operacij in misij: analiza UNAMSIL (Sierra Leone)”. Diploma thesis. University of Ljubljana, 2013. Palko, T. “Analiza uspešnosti operacij EU in OZN v DR Kongo”. Diploma 
thesis. University of Ljubljana, 2011; Grošelj, U. "Analiza uspeha mirovne operacije Združenih narodov v Somaliji II". Diploma thesis. University of Ljubljana, 2009. 